\title{
A new species of Xenylla (Collembola: Poduromorpha: Hypogastruridae) with new records for the state of Espirito Santo, southeastern Brazil
}

\author{
Liliane Henriques Fernandes \& Maria Cleide de Mendonça
}

\begin{abstract}
Departamento de Entomologia, Museu Nacional, Universidade Federal do Rio de Janeiro. Quinta da Boa Vista, São Cristóvão, 20940-040 Rio de Janeiro, Brasil. E-mail: lilianefer@gmail.com; mcleide@acd.ufrj.br
\end{abstract}

\begin{abstract}
A new species of Xenylla Tullberg, 1869, X. capixaba sp. nov., is described and illustrated. In addition, we present a list with new records of Poduromorpha from the state of Espírito Santo, Brazil. Xenylla yucatana Mills, 1938 and Brachystomella platensis Najt \& Massoud, 1974 are for the first time recorded in Brazil. Also, the distributions of $B$. ceciliae Fernandes \& Mendonça, 2004, B. contorta Denis, 1931 and Arlesia albipes (Folsom, 1927) are expanded to include Espírito Santo. Brachystomella agrosa Wray, 1953, previously recorded in agricultural soils, was also found in a marine environment. KEY WORDS. Bracystomellidae; collembolan diversity; list of species; Neanuridae.
\end{abstract}

This study is part of a broader project that aims to investigate the composition and distribution of Collembola Poduromorpha communities in sand shores. Despite the rich collembolan diversity in coastal ecosystems, research on this group in Brazil is still limited to the coastal sand plains of the state of Rio de Janeiro (Mendonça \& Fernandes 1997, Fernandes \& MENDONÇA 2004, 2007).

In order to expand our knowledge on the Poduromorpha inhabiting other Brazilian shores, we performed preliminary sampling in stretches on the coast of the state of Espírito Santo. Only two species, Anurida maritima (Guérin, 1838) and Fissuraphorura cubanica Rusek, 1991, had been previously recorded in this region (Arlé 1981, Thibaud \& Palacios-Vargas 1999).

The material resulting from samples obtained from the vegetation that covers sandy dunes, rocks and intertidal zone sands of the beaches surveyed revealed a new species of Xenylla Tullberg, 1869, which is described and illustrated below. In addition, X. yucatana Mills, 1938 and Brachystomella platensis Najt \& Massoud, 1974 are recorded for the first time in Brazil, and the distributions of B. ceciliae Fernandes \& Mendonça, 2004, B. contorta Denis, 1931 and Arlesia albipes (Folsom, 1927) are expanded to include the state of Espírito Santo. Brachystomella agrosa Wray, 1953, previously recorded in agricultural soils by Culik et al. (2006), was also found in a marine environment.

\section{MATERIAL AND METHODS}

The study area is located on the coast of the state of Espírito Santo, and consists of a $430 \mathrm{~km}$ stretch that borders the state of Bahia $\left(39^{\circ} 30^{\prime} \mathrm{W}, 18^{\circ} 28^{\prime} \mathrm{S}\right)$ in the North and the state of Rio de Janeiro $\left(41^{\circ} 00^{\prime} \mathrm{W}, 21^{\circ} 15^{\prime} \mathrm{S}\right)$ in the south. The littoral formation by quaternary deposits is present in almost the entire area (Fraga \& Peixoto 2004). The local vegetation is part of the physiognomy of the Atlantic Rainforest. The climate, according to Köppen's classification system, is tropical with a hot and rainy summer and a dry winter (Aw). It has an annual average temperature of $23.3^{\circ} \mathrm{C}$, precipitation of $1,307 \mathrm{~mm}$ of and and relative humidity of $80 \%$ (Assis et al. 2004).

Sampling was conducted in the municipalities of Guarapari and Vila Velha (Fig. 1), located in the central mesoregion, in the following sampling stations: Station 1 - samples \#1141, 1142, and 1143 - Parque Estadual Paulo César Vinha, Guarapari, litter over sandy dune, 23/VII/2001; Station 2 samples \# 1144 and 1145 - Praia de Itaparica, Vila Velha, beach sand, 23/VII/2001; Station 3 - samples \#1146 and 1147Enseada Azul, Praia da Bacutia, Guarapari, moss and soil over beach rocks, 24/VII/2001.

The springtails were obtained from random samples of litter and sand with the aid of a cylindrical apparatus. In the laboratory, the specimens were extracted using a BerleseTullgren funnel, fixed in boiling alcohol and kept at 96\% ethanol. The methodology of ARLÉ \& MENDONÇA (1982) was used in the study of the external morphology. The collected material is deposited in the Collembola Collection of the Museu Nacional, Universidade Federal do Rio de Janeiro (CM/MNRJ).

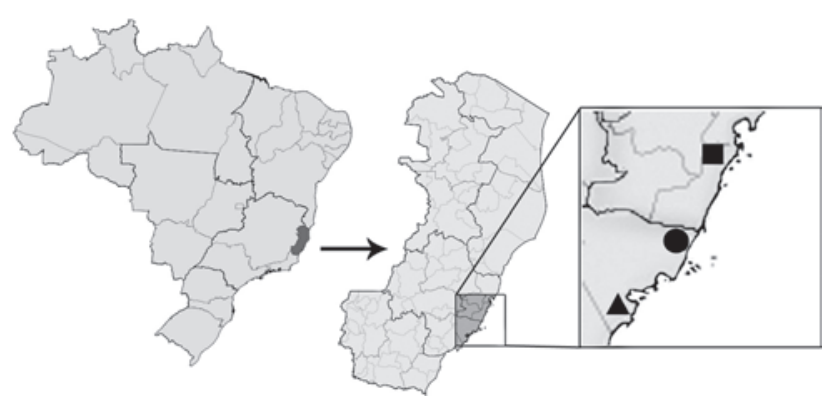

Figure 1. Map of Brazil indicating the location of the state of Espírito Santo and the locations of the sampling stations: $(\mathbf{A})$ Station 1, (•) Station 2, (ם) Station 3. 


\section{TAXONOMY}

\section{Hypogastruridae}

\section{Xenylla capixaba sp. nov. \\ Figs 2-8}

Diagnosis. Body lenght 630-1200 $\mu \mathrm{m}$. Coloration dark grey. Body tegument strongly granulated. Body and cephalic dorsal chaetotaxy with ciliated, apically round setae; smooth thin sensillae are twice the length of common setae (Fig. 2); body and cephalic ventral chaetotaxy with smooth thin setae. Antennae shorter than head diagonal. Antennal segment IV apical vesicle bearing one granulated lobe; one subapical organite; one lateral microsensillum; five sensillae with the two dorsal-external sensillae thicker than the others. Sensory organ of antennal segment III formed by two rounded granulated microsensilla inside a fold of the tegument, two small subcylindrical guard sensillae; one ventral microsensillum. Antennal segments I and II with seven and 12 setae, respectively (Fig. 3). Eye patches strongly pigmented with 5+5 eyes; postantennal organ absent. Chewing mouthparts typical of the genus; maxillary outer lobe with one sublobal hair; labral chaetotaxy formula: $4 / 5 / 5 / 4$. Tibiotarsi I-III, respectively, with $19,19,18$ setae, being two of them long spatulate tenent hairs, per leg. Ungues measuring $37 \mu \mathrm{m}$, with one small inner tooth near apex; unguiculus absent (Fig. 4).

Ventral tube with $4+4$ setae. Retinaculum with $3+3$ teeth. Manubrium with about 35 setae on posterior side; dens (40 $\mu \mathrm{m})$ with two dorsal setae; mucro narrowed and elongate (25 $\mu \mathrm{m})$, clearly separated from dens, with lobed lamella on basal part (Figs 5 and 6). Presence of two anal spines ( $5 \mu \mathrm{m}$ ) on weakly developed papillae. Anal valve with $14+14$ setae and $2+2 \mathrm{hr}$ setae. Genital plate of female with two eugenital and eight circungenital setae (Fig. 5); genital plate of male with six eugenital setae and 21 circungenital setae (Fig. 7).

Dorsal chaetotaxy (b, h1, h2, i, q): Head with a0, c2, c3 and $\mathrm{d} 1$ setae, with $\mathrm{L} 1$ as long as L3, and both longer than the others; seta c1 absent (b). Thoracic segment I with 3+3 setae. Thoracic segments II and III with setae la2, m3 and p3; seta a2 displaced apically compared with seta a1 (h1); seta p2 displaced apically compared with seta p1 (h2); seta la1 absent (i). Abdominal segment III with $4+4$ setae between the sensillae in posterior row. Abdominal segment IV with p3 and m3; seta p5 $=$ Ss. Abdominal segment $\mathrm{V}$ without seta $\mathrm{a} 2$ (q).

Ventral chaetotaxy (t, a3): Head with $\mathrm{m} 3$ and $\mathrm{p} 1$ (Fig. 8). Thoracic segments II and III without pair of medial setae (t). Abdominal segment II with p1, p2 and p6. Abdominal segment III with seta a6; seta p5 absent (a3). Abdominal segment IV with seta $\mathrm{m} 1$ (Fig. 5).

Type locality: Parque Nacional Paulo César Vinha, Guarapari, State of Espirito Santo, Brazil. Found on sand dune litter.

Type material. BraziL, Espírito Santo: Guarapari (Parque Estadual Paulo César Vinha), female holotype on slide $\mathrm{N}^{\circ} 1142$
CM/MNRJ, 23/VII/2001, L.H. Fernandes leg. Paratypes, same data as holotype: 7 specimens on slide $\mathrm{N}^{\circ} 1141 ; 5$ specimens on slide $\mathrm{N}^{\circ} 1142,23 / \mathrm{VII} / 2001$, L.H. Fernandes leg.

Etymology. The new species is named after the common name ("capixaba") of the people from the State of Espirito Santo.

Remarks. Xenylla Tullberg, 1869, which has a cosmopolitan distribution, includes 123 currently recognized species (Bellinger et al. 1996-2008). In Brazil, this genus is poorly known and only five species have been recorded. Two of them, $X$. brasiliensis Gama, 1978 and X. nirae Gama \& Oliveira, 1994, were described from the states of Minas Gerais and Amazonas, respectively. Xenylla welchi Folsom, 1916 was recorded for the states of Espírito Santo and Rio de Janeiro (Culik et al. 2002, Fernandes \& Mendonça 2007), and X. maritima Tullberg, 1869 was recorded from the state of Rio de Janeiro (Fernandes \& MENDONÇA 2004).

Xenylla capixaba sp. nov. resembles $X$. welchi Folsom, 1916 and $X$. marina Lee, Park \& Park, 2005. These three species share the $5+5$ eyes, head with seta L1 as long as L3, tibiotarsus with two tenent hairs, ungues with small inner tooth near the apex, ventral tube with $4+4$ setae, retinaculum bearing $3+3$ teeth and dens separated from the mucro with two dorsal setae. The new species differs from $X$. welchi and $X$. marina due in characters of the chaetotaxy, granulation on the apical organ and the number of sensilla on the antennal segment IV, and the shape of the mucro. Xenylla capixaba sp. nov. and X. marina also share the presence of spatulate tenent hairs on the tibiotarsi, which are different from those shown by $X$. welchi. The new species is easily distinguished from $X$. welchi, $X$. marina and the other species of the genus by the dorsal chaetotaxy formed by ciliated setae.

\section{Xenylla yucatana Mills, 1938}

Material examined. Station 2, Sample \# 1144, 463 specimens.

Remarks. Species of Neotropical, Afrotropical, Oriental and Australasian distribution (BARRA 2006), recorded on beach sand in Brazil for the first time.

\section{Brachystomellidae}

\section{Brachystomella agrosa Wray, 1953}

Material examined. Station 1, Sample \# 1141, four specimens, Sample \# 1142, 23 specimens; Station 2, Sample \# 1144, two specimens, Sample \# 1145, 15 specimens; Station 3, Sample \# 1146, one specimen, Sample \# 1147, six specimens.

Remarks. Neotropical species with broad distribution in Brazil, already recorded from the states of Rio de Janeiro, Espírito Santo, Pernambuco, Paraíba, Bahia and São Paulo (MendonçA \& Arlé 1992, Bellini \& Zeppelini 2004, Fernandes \& Mendonça 2004, Culik et al. 2006). Brachystomella agrosa was recorded in the state of Espírito Santo in agricultural soil. The present record increases its distribution to the littoral environment. 


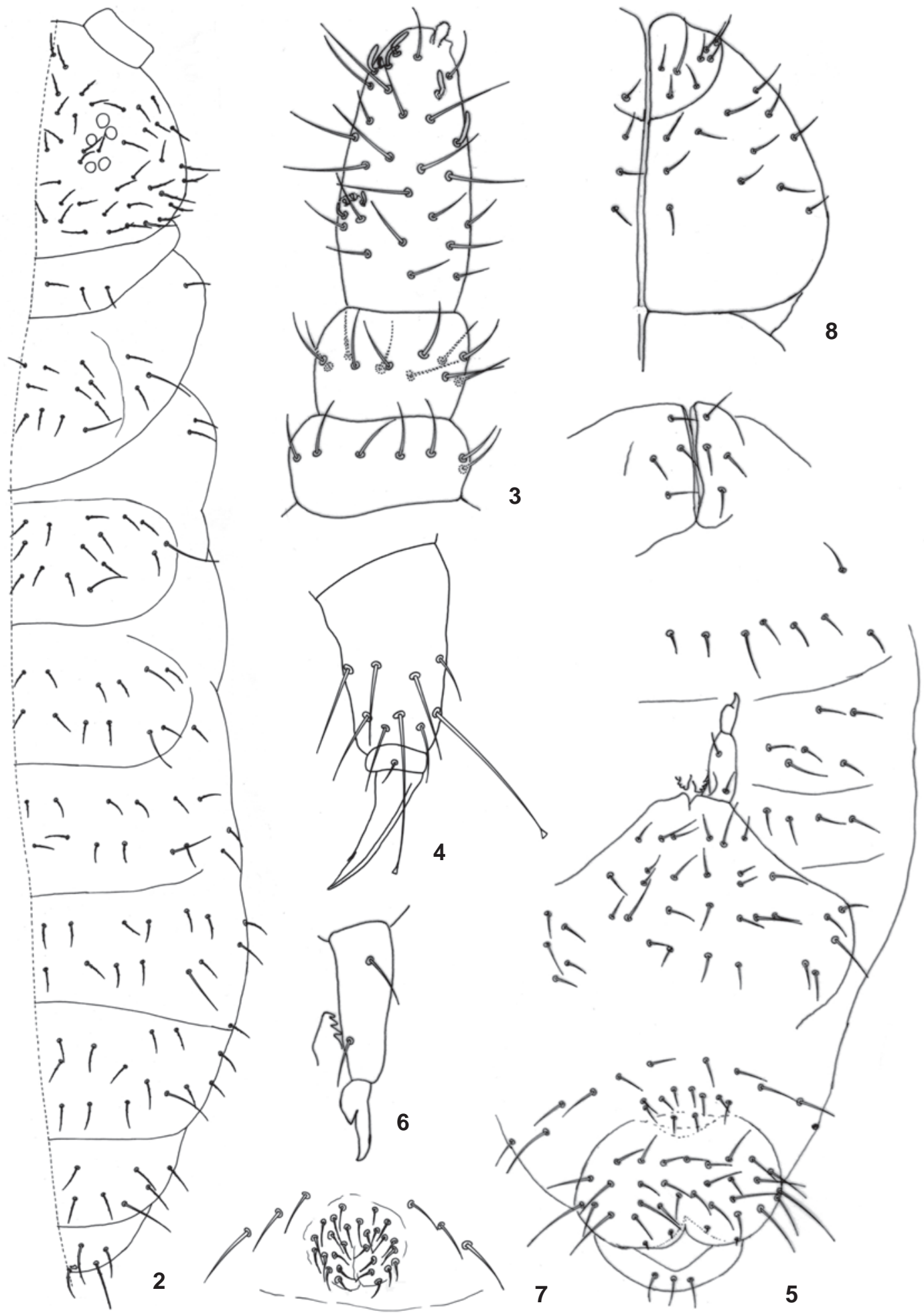

Figures 2-8. Xenylla capixaba sp. nov.: (2) dorsal chaetotaxy; (3) antenna; (4) unguis and tibiotarsus I; (5) abdominal ventral chaetotaxy; (6) retinaculum, dens and mucro; (7) genital plate of male; (8) cephalic ventral chaetotaxy. 


\section{Brachystomella ceciliae Fernandes \& Mendonça, 2004}

Material examined. Station 1, Sample \# 1142, one specimen.

Remarks. Species described from the littoral of Rio de Janeiro, where it was collected on Maricá coastal sand plain. It is recorded for the first time from Espírito Santo, confirming its preference in littoral environments.

\section{Brachystomella contorta Denis, 1931}

Material examined. Station 2, Sample \#1145, four specimens; Station 3, Sample \# 1146, one specimen.

Remarks. Species with wide ecological valence and geographical distribution (NAjt \& Palacios-Vargas 1986), already recorded from Brazil in the Maricá coastal sand plain (FERNANDES \& MENdOnçA 2004, 2007) in halophyte-psammophyte vegetation areas and foredune zone, as well as in impacted areas. It is herein recorded from Espírito Santo for the first time.

\section{Brachystomella platensis Najt \& Massoud, 1974}

Material examined. Station 1, Sample \# 1141, one specimen; Station 2, Sample \# 1144, 15 specimens.

Remarks. Species described based on samples collected from forest litter in Argentina and later recorded from Australia by GREensLAde \& Najt (1987) in litter, fungi, Eucalyptus forest, prairies, turnip culture and grazing land. It is recorded in dune and beach sand litter for the first time in Brazil.

\section{Neanuridae}

\section{Pseudachorutinae}

\section{Arlesia albipes (Folsom, 1927)}

Material examined. Station 1, Sample \# 1143, one specimen.

Remarks. Neotropical species with wide distribution in Brazil, previously recorded for the states of Rio de Janeiro, Pernambuco, Pará, Minas Gerais, and Amazonas (ArLé 1962, 1966, ArLÉ \& Rufino 1976). Its distribution is here expanded to the State of Espírito Santo.

\section{ACKNOWLEDGMENTS}

The authors thank Fundação de Amparo à Pesquisa do Estado do Rio de Janeiro (FAPERJ) and Petróleo Brasileiro S.A. (PETROBRAS) for financial support, as well as the anonymous reviewers for their helpful comments.

\section{LITERATURE CITED}

Assis, A.M.de; O.J. Pereira \& L.D. Thomaz. 2004. Fitossociologia de uma floresta de restinga no Parque estadual Paulo César Vinha, Setiba, município de Guarapari,(ES). Revista Brasileira de Botânica 27 (2): 349-361.
Arlé, R. 1962. Sobre Pseudachorutidae da região amazônica (Collembola). Atas da Sociedade de Biologia do Rio de Janeiro 6 (1-2): 1-3.

Arlé, R. 1966. Collemboles d'Amazonie. I. Poduromorphes nouveaux ou peu connus et notes biologiques sur Neotropiella carli (Denis). Boletim do Museu Paraense Emilio Goeldi, Nova Série, Zoologia, 60: 1-19.

Arlé, R. 1981. Conspecto das espécies brasileiras de Pseudachorutinae, com descrição de uma espécie nova da Colômbia (Insecta, Collembola). Acta Amazonica 11 (3): 583-593.

Arlé, R. \& C. MendonçA. 1982. Estudo preliminar das espécies de Dicranocentrus Schött, 1893, ocorrentes no Parque Nacional da Tijuca, Rio de Janeiro (Collembola). Revista Brasileira de Biologia 42 (1): 41-49.

Arlé, R. \& E. Rufino. 1976. Contribuição ao conhecimento dos Pseudachorutinae da Amazônia (Collembola). Acta Amazonica 6 (1): 99-107.

Bellinger, P.F.; K.A. Christiansen \& F. Janssens. 1996-2008. Checklist of the Collembola of the World. Available online at: http://www.collembola.org [Acessed: 01/X/2008].

Beluini, B.C. \& D. Zeppelini. 2004. First records of Collembola (Ellipura) from the State of Paraíba, Northeastern Brazil. Revista Brasileira de Entomologia 48 (4): 587-588.

BARRA, J.-A. 2006. Collemboles de l'Ile de Socotra, Republique du Yémen. Zoosystema 28 (1): 61-74.

Culik, M.P; J.L. de Souza \& J.A. Ventura. 2002. Biodiversity of Collembola in tropical agricultural environments of Espírito Santo, Brazil. Applied Soil Ecology 21: 49-58.

Culik, M.P; D. dos S. Martins \& J.A. Ventura. 2006. Collembola (Arthropoda: Hexapoda) communities in the soil of Papaya Orchads managed with conventional and integrated production in Espírito Santo, Brazil. Biota Neotropica 6 (3): 1-8.

Fernandes, L.H. \& C. Mendonça. 2004. Collembola Poduromorpha do litoral de Maricá, Rio de Janeiro, Brasil. Revista Brasileira de Zoologia 21 (1): 15-25.

Fernandes, L.H. \& C. Mendonça. 2007. Collembola Poduromorpha de áreas preservadas e impactadas do litoral sudeste do Brasil. Revista Brasileira de Zoologia 24 (3): 777 785.

Fraga, C.N. \& A.L. Peixoto. 2004. Florística e ecologia das Orchidaceae das restingas do estado do Espírito Santo. Rodriguésia 55 (84): 5-20.

Greenslade, P. \& J. Najt. 1987. Collemboles Brachystomellinae de l'Australie I. Les genres Brachystomella et Rapoportella. Annales de la Societé Entomologique de France (N.S.) 23 (4): 435-453.

MendonçA, C. \& R. Arlé. 1992. Variação quetotáxica em Brachystomella agrosa Wray, 1953 (Collembola, Neanuridae). Boletim do Museu Nacional, Nova Série, Zoologia, 351: 1-9.

Mendonça, C. \& L.H. Fernandes. 1997. A new genus of Brachystomellinae from Brazil (Collembola: Neanuridae). Boletim do Museu Nacional, Nova Série, Zoologia, 379: 1-7.

Najt, J. \& J.G. Palacios-Vargas. 1986. Nuevos Brachystomellinae 
de México (Collembola, Neanuridae). Nouvelle Revue d'Entomologie 3 (4): 457-471.

Thibaud, J.-M. \& J.G. Palacios-Vargas. 1999. Brazilian Collembola from littoral sand with description of Austrogastrura gen. n. and Isotomodes carioca sp. nov. [Hypogastruridae; Isotomidae]. Revue Française d'Entomologie (N.S.) 21 (1): 25-31.

Submitted: 11.III.2009; Accepted: 27.I.2010.

Editorial responsibility: Gabriel Mejdalani 